\title{
Biochar and mucuna increase papaya plant growth and nutrition, as well as soil fertility ${ }^{1}$
}

\author{
Renato Veloso da Silva², Luciana Aparecida Rodrigues², \\ Maurício Gonçalves da Silva², Bruna Gandini da Silva ${ }^{2}$, Marco Antônio Martins ${ }^{2}$
}

\section{ABSTRACT}

The association between biochar and green manure in the papaya crop may be a promising management technique, mainly in its first growth stage. This study aimed to evaluate the effects of biochar and green manure (Mucuna aterrina) on the growth and nutrition of Carica papaya seedlings, as well as on soil fertility. The experiment followed a randomized block design ( 5 blocks), in a 2 × 2 factorial arrangement: with and without mucuna and with and without biochar. The biochar or mucuna application significantly increased the papaya plant shoot and root growth, as well as the chemical features of the soil, whereas their joint application did not provide synergistic effects, except for the leaf $\mathrm{P}$ concentration. The application of biochar and biochar + mucuna enabled a fast initial increase in plant height. However, it also showed a visible $\mathrm{N}$ deficiency, despite the increased $\mathrm{N}, \mathrm{P}, \mathrm{K}, \mathrm{Ca}$ and $\mathrm{Mg}$ accumulation and use efficiency in the plants. The effect of the biochar/mucuna joint application is synergistic for the leaf $\mathrm{P}$ content and plant height. The individual or joint application of biochar and mucuna increases the papaya plant growth and nutrition and maintains the soil fertility.

KEYWORDS: Carica papaya L., Mucuna aterrina, green manure.

\section{INTRODUCTION}

Papaya (Carica papaya L.) crops have been notably increasing due to fruit exports, mainly to the European market. The biggest papaya producers in Brazil are found in the Espírito Santo and southern Bahia states (ABF 2018).

Given the potential of this crop, as well as the growing demand for nutrients, both in the seedling production and in production fields, and the high costs with the acquisition of mineral fertilizers, less costly

\section{RESUMO}

Biochar e mucuna incrementam o crescimento e nutrição de mamoeiro, bem como a fertilidade do solo

A associação de biochar a adubos verdes no cultivo de mamoeiro pode ser uma técnica de manejo promissora, principalmente em sua primeira fase de cultivo. Objetivou-se avaliar os efeitos de biochar e adubo verde (Mucuna aterrina) no crescimento e nutrição de mudas de Carica Papaya e na fertilidade do solo. O experimento foi conduzido em blocos casualizados ( 5 blocos), em esquema fatorial $2 \times 2$ : presença e ausência de mucuna e presença e ausência de biochar. No crescimento da parte aérea e das raízes do mamoeiro, e também nas características químicas do solo, a aplicação de biochar ou mucuna resultou em incrementos significativos, enquanto a aplicação conjunta não proporcionou efeitos sinergísticos, exceto para o teor foliar de P.A aplicação de biochar e de biochar + adubo verde proporcionou rápido crescimento inicial em altura das plantas. No entanto, apresentou, também, deficiência visível de $\mathrm{N}$, apesar dos maiores conteúdos e eficiência de utilização de N, P, K, Ca e Mg nas plantas. O efeito da aplicação conjunta de biochar e mucuna é sinérgico para o teor foliar de $\mathrm{P}$ e altura das plantas. A aplicação individual ou em conjunto de biochar e mucuna aumenta o crescimento e nutrição de plantas de mamão e mantém a fertilidade do solo.

PALAVRAS-CHAVE: Carica papaya L., Mucuna aterrina, adubo verde.

alternatives have been investigated. Most techniques focus on improving the physical, chemical and biological soil conditions through the application of conditioners, additives and fertilizers, among others (Kratz et al. 2013). Green manure stands out among these techniques, due to its positive effects on the physical, biological and fertility properties of the soil.

Green manure biomass should be applied to and incorporated in the soil, and the source plant should be grown simultaneously, in rotation, with the commercial crop (Costa \& Costa 2003) or in an

1. Received: Oct. 01, 2018. Accepted: Apr. 09, 2019. Published: Jul. 10, 2019. DOI: 10.1590/1983-40632019v4955210.

2. Universidade Estadual do Norte Fluminense Darcy Ribeiro, Centro de Ciências e Tecnologias Agropecuárias,

Campos dos Goytacazes, RJ, Brasil.E-mail/ORCID: renatorural@hotmail.com/0000-0003-4933-6341,

lucianaaparecidarodrigues@gmail.com/0000-0002-5335-1985,mauriciosilva2008@hotmail.com/0000-0003-4052-0492, brunagandini@hotmail.com/0000-0002-5499-7147,marco@uenf.br/0000-0001-6394-3880. 
adjacent area (between planting lines). In addition, green manure can be used in association, or not, with other management techniques, to enable the best use of biomass nutrients. This application can be mainly performed by small farmers or in crop management systems such as organic crops, which make a restricted use of mineral fertilizers.

The controlled use of agricultural and industrial waste in crops has also been tested in order to reduce costs with inappropriate disposal and with the proper destination given to this waste. Waste such as biochar can be processed and become products with commercial value. The biochar or charcoal production derives from knowledge acquired from studies on black Indian soil, according to which a high soil fertility is associated with the presence of charcoal from domestic and agricultural crop waste burning. Biochar derives from the plant or animal biomass pyrolysis process in the absence of oxygen or under low concentrations of it (Novotny et al. 2015). The material generated through this process presents a $\mathrm{C}$ content higher than $50 \%$. Moreover, it is stabilized and resistant to decomposition when applied to the soil (Mangrich et al. 2011). Biochar often presents a wide specific surface area with exposed load, which leads to a high cation exchange capacity and increases the nutrient retention when applied to the soil (Novotny et al. 2015). In addition, biochar presents high levels of available nutrients, depending on the raw material used in its production (Mukherjee \& Zimmerman 2013). These nutrients can reduce the total amount of fertilizer to be applied into the soil, as well as increase growth and contribute to plant nutrition (Martins 2018). The biochar application into the soil enables the $\mathrm{pH}$ elevation, water retention (Novotny et al. 2015) and adsorption and/or complexation of toxic components such as heavy metals and toxic organic compounds. Besides, it also influences the microbial population in the soil (Sun et al 2015, Barcelos et al. 2017).

Biochar is used in association with other management techniques, such as green manure, in order to trigger synergistic effects on plant growth and mineral nutrition (Partey et al. 2014), as well as to increase the soil fertility (Novotny et al. 2015, Martins 2018) and reduce the use of fertilizers. This joint technique may also be efficient in papaya crops.

Thus, this study aimed to evaluate the effect of the application of green manure, biochar and biochar + green manure on the nutrition and initial growth of papaya shoot and roots and on the chemical attributes of the soil.

\section{MATERIAL AND METHODS}

The experiment was conducted in a greenhouse (low density polyethylene cover and screens with shading of $30 \%$ ) at the Universidade Estadual do Norte Fluminense, in Campos dos Goytacazes, Rio

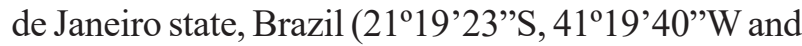
altitude of 20-30 m), from March to June 2016. The climate of the region is classified as Aw, according to Köppen, being tropical hot and humid, with a dry season in the winter, rainy in the summer and annual precipitation around 1,152 mm (Köppen 1948).

It followed a randomized block design, in a 2 x 2 factorial arrangement, with and without biochar $\mathrm{x}$ with and without green manure, with five repetitions. A clayey soil presenting the following chemical attributes was used in the experiment (Claessen et al. 1997): $\mathrm{pH}$ (water) $=5.3$; $\mathrm{P}=5.0 \mathrm{mg} \mathrm{dm}^{-3}$ and $\mathrm{K}=100.0 \mathrm{mg} \mathrm{dm}^{-3}$ (extractor: $\left.\mathrm{H}_{2} \mathrm{SO}_{4} 0.0125 \mathrm{~mol} \mathrm{~L}^{-1}+\mathrm{HCl} 0.05 \mathrm{~mol} \mathrm{~L}^{-1}\right)$; $\mathrm{Ca}=1.0 \mathrm{cmol}_{\mathrm{c}} \mathrm{dm}^{-3}, \mathrm{Mg}=0.5 \mathrm{cmol}_{\mathrm{c}} \mathrm{dm}^{-3}$ and $\mathrm{Al}=0.0 \mathrm{cmol}_{\mathrm{c}} \mathrm{dm}^{-3}$ (extractor: $\left.\mathrm{KCl} 1 \mathrm{~mol} \mathrm{~L}^{-1}\right)$; $\mathrm{H}+\mathrm{Al}=1.9 \mathrm{cmol}_{\mathrm{c}} \mathrm{dm}^{-3}($ calcium acetate $\mathrm{pH} 7) ; \mathrm{T}=$ $3.7 \mathrm{cmol}_{\mathrm{c}} \mathrm{dm}^{-3} ; \mathrm{t}=1.8 \mathrm{cmol} \mathrm{dm}_{\mathrm{c}}^{-3} ; \mathrm{V}=48 \% ; \mathrm{OM}=$ $16.6 \mathrm{~g} \mathrm{dm}^{-3}$ (potassium dichromate), $\mathrm{Fe}=32.0 \mathrm{~g} \mathrm{dm}^{-3}$, $\mathrm{Cu}=0.4 \mathrm{~g} \mathrm{dm}^{-3}, \mathrm{Zn}=1.4 \mathrm{~g} \mathrm{dm}^{-3}, \mathrm{Mn}=5.9 \mathrm{~g} \mathrm{dm}^{-3}$ and $\mathrm{B}=0.8 \mathrm{~g} \mathrm{dm}^{-3}$ (extractor: $\mathrm{H}_{2} \mathrm{SO}_{4} 0.0125 \mathrm{~mol} \mathrm{~L}^{-1}+$ $\left.\mathrm{HCl} 0.05 \mathrm{~mol} \mathrm{~L}^{-1}\right)$.

The soil received $0.29 \mathrm{~g} \mathrm{dm}^{-3}$ of limestone (PRNT $80 \%$ ) to reach $60 \%$ of base saturation. It was also homogenized, fed to $60 \%$ of the field capacity and incubated in closed containers for 30 days. All treatments were fertilized with $15 \mathrm{mg} \mathrm{dm}^{-3}$ of $\mathrm{P}$ in the form of Araxá phosphate, and with $25 \mathrm{mg} \mathrm{dm}^{-3}$ of $\mathrm{K}$ as $\mathrm{KCl}$.

The herein used biochar was generated through a poultry litter pyrolysis process conducted at $400{ }^{\circ} \mathrm{C}$, by the SP - Pesquisa e Tecnologia Ltda. (SPPT), in Mogi-Mirim, São Paulo state, Brazil. It presented the following chemical characterization: $\mathrm{N}_{\text {total }}=$ $31.80 \mathrm{~g} \mathrm{~kg}^{-1} ; \mathrm{P}=29.40 \mathrm{~g} \mathrm{~kg}^{-1} ; \mathrm{K}=47.20 \mathrm{~g} \mathrm{~kg}^{-1} ; \mathrm{Ca}=$ $48.30 \mathrm{~g} \mathrm{~kg}^{-1} ; \mathrm{Mg}=14.60 \mathrm{~g} \mathrm{~kg}^{-1} ; \mathrm{S}=10.00 \mathrm{~g} \mathrm{~kg}^{-1} ; \mathrm{Al}=$ $15.50 \mathrm{~g} \mathrm{~kg}^{-1} ; \mathrm{Na}=7.30 \mathrm{~g} \mathrm{~kg}^{-1} ; \mathrm{Fe}=8.50 \mathrm{~g} \mathrm{~kg}^{-1} ; \mathrm{Zn}=$ $1.07 \mathrm{~g} \mathrm{~kg}^{-1} ; \mathrm{Cu}=0.6 \mathrm{~g} \mathrm{~kg}^{-1} ; \mathrm{B}=0.48 \mathrm{~g} \mathrm{~kg}^{-1} ; \mathrm{Mn}=$ $0.65 \mathrm{~g} \mathrm{~kg}^{-1} ; \mathrm{C}_{\text {total }}=429.00 \mathrm{~g} \mathrm{~kg}^{-1} ;$ moisture $=2.8 \%$; CEC $=80.00 \mathrm{mmol}_{\mathrm{c}} \mathrm{kg}^{-1}$. In total, $2.76 \mathrm{~g} \mathrm{dm}^{-3}$ of 
biochar $(1 \% \mathrm{v} / \mathrm{v})$ - which corresponded to $5.5 \mathrm{tha}^{-1}$ were applied to the soil.

Mucuna-preta [Mucuna aterrina (Piper \& Tracy)], grown in pots filled with $10 \mathrm{dm}^{3}$ of soil under greenhouse conditions, until flowering onset, was the green manure used to compose the treatments. The plant shoot was cut (in segments of $2 \mathrm{~cm}$ ) with a chopping machine and incorporated into the experimental soil, in treatments whose management was based on the mucuna application. The soil presenting mucuna roots was not used in the experiment, since the soil where it was previously cultivated in was subjected to liming, and that could influence the attributes of the investigated soil and the effect of green manure. A mucuna shoot sample was selected for mineral composition analysis (Malavolta 2006), presenting the following macro and micronutrient concentrations: $\mathrm{N}=30.38 \mathrm{~g} \mathrm{~kg}^{-1}$; $\mathrm{P}=1.23 \mathrm{~g} \mathrm{~kg}^{-1} ; \mathrm{K}=9.98 \mathrm{~g} \mathrm{~kg}^{-1} ; \mathrm{Ca}=11.28 \mathrm{~g} \mathrm{~kg}^{-1}$; $\mathrm{Mg}=2.29 \mathrm{~g} \mathrm{~kg}^{-1} ; \mathrm{Fe}=734 \mathrm{mg} \mathrm{kg}^{-1} ; \mathrm{Cu}=16 \mathrm{mg} \mathrm{kg}^{-1}$; $\mathrm{Zn}=40 \mathrm{mg} \mathrm{kg}^{-1}$; and $\mathrm{Mn}=54 \mathrm{mg} \mathrm{kg}^{-1}$. A total of $25 \mathrm{~g}$ of fresh mucuna per $\mathrm{dm}^{3}$ of soil were added to the already chopped pots (fresh matter at $73 \%$ of humidity), in treatments based on green manure; $50 \%$ of mucuna was incorporated into the soil and the other $50 \%$ were placed over the ground. This value was based on the mean fresh green manure biomass per hectare, which was produced and incorporated into the soil (Suzuki \& Alves 2006).

Papaya seeds were removed from fruits belonging to the Carica Papaya L. (Gold cultivar, Solo group) species, which were produced by the company Caliman Agrícola S. A. The seeds were placed for water absorption for $1 \mathrm{~h}$, and then washed with running water to remove the mucilage covering them.

After the soil incubation period was over, both the biochar and green manure were incorporated into it, and this procedure was followed by sowing. Six papaya seeds were placed in each pot $\left(4 \mathrm{dm}^{3}\right)$ and covered with a small portion of soil - irrigation was performed after sowing. Each pot was irrigated with water up to $100 \%$ of the field capacity - every 15 days, by taking into consideration the different needs of irrigation in each treatment - carefully added until leaching was observed. The amount of water added to each pot, in order to reach approximately $100 \%$ of its field capacity, was measured and $60 \%$ of such amount were used for irrigation purposes for the following 15 days. The irrigation procedure was kept until harvest.
Thinning was performed in plants presenting two leaves, on average, after seedling germination and establishment, in order to leave three seedlings per pot. Plant height was individually measured with a millimeter ruler, every 10 days.

At 60 days after sowing, seed samples were collected at $5 \mathrm{~cm}$ and $15 \mathrm{~cm}$ of depth in the soil in the pots for microbial analysis, $10 \mathrm{~g}$ of soil were weighed, $90 \mathrm{~mL}$ of sterilized saline solution $(0.85 \%)$ were added to it and the mixture was homogenized in a shaker incubator at $170 \mathrm{rpm}$, for $30 \mathrm{~min}$, to form the suspension solution. The serial dilution (between $10^{-3}$ and $10^{-6}$ ) was performed based on the suspension solution. In order to do so, $1 \mathrm{~mL}$ of suspension solution was transferred to test tubes filled with $9 \mathrm{~mL}$ of sterile (saline) solution and homogenized to enable a $10^{-2}$ dilution. A dose of $1 \mathrm{~mL}$ of the $10^{-2}$ diluted solution was transferred to another test tube filled with $9 \mathrm{~mL}$ sterile (saline) solution, which corresponded to a $10^{-3}$ dilution. This procedure was successively performed until the dilution reached $10^{-6}$ (Wollum 1982).

A $100 \mu \mathrm{L}$ aliquot (from $10^{-3}$ to $10^{-6}$ dilutions) of suspension solution was transferred to Petri dishes for colony growth in Bunt \& Rovira (1955) medium at $\mathrm{pH}$ 6.5-7.0, in the presence of cyclohexamide $\left(10 \mu \mathrm{g} \mathrm{mL}^{-1}\right)$, for bacterial count purposes; as well as in the Martin (1950) medium, at $\mathrm{pH}$ 5.6, in the presence of streptomycin $\left(100 \mu \mathrm{g} \mathrm{mL}^{-1}\right)$ and rose bengal $\left(70 \mu \mathrm{g} \mathrm{mL}^{-1}\right)$, for fungal count purposes. The Petri dishes were kept in a BOD with inverted lid, at $28{ }^{\circ} \mathrm{C}$, for up to 7 days, and colonies were evaluated and counted on a daily basis. The number of microorganisms was calculated based on the following equation, with results expressed in number of microorganisms (NM) per gram of soil: $\mathrm{NM}=$ [number of colonies $*$ (1/dilution factor $) *$ (1/aliquot)]/soil dry mass.

Approximately at 80 days after sowing, the plants started showing the first nutritional deficiency symptoms. Ten days later, the green color intensity of the second leaf from the base of plants subjected to each treatment was read in a portable chlorophyll determiner SPAD-502 - Soil and Plant Analysis Development (MCCL 1989). Four measurements of SPAD values were taken on each evaluated leaf.

The stem base diameter was measured with a digital caliper at 90 days after sowing. Plant shoot was harvested and dried in an oven with forced air circulation at $60{ }^{\circ} \mathrm{C}$, to enable quantifying the 
shoot dry mass. Next, the samples were subjected to nitric-perchloric digestion, and the $\mathrm{P}, \mathrm{K}, \mathrm{Ca}$ and $\mathrm{Mg}$ concentrations in the plant shoot were determined and the accumulation of these elements was calculated. Sulfuric digestion was assessed to determine the N concentration (Malavolta 2006).

The nutrient accumulation was calculated by multiplying the concentration of each nutrient by the shoot dry matter, whereas the nutrient use efficiency (UE) was calculated based on the equation by Sidique \& Glass (1981), wherein DM is the dry matter $(\mathrm{g})$ and the accumulation is expressed as g plant $^{-1}: \mathrm{UE}=[(\mathrm{DM} * \mathrm{DM}) \div$ acumulation $]$.

Soil samples were collected, air dried in the shade and subjected to chemical analysis (Claessen et al. 1997). Roots were washed with water jets, manually collected and screened in an Epson Expression 10000XL Scanner, at $15 \mathrm{~cm}$ x $25 \mathrm{~cm}$ cuvette. The digitalized images were assessed in the WinRhizo software, version 3.8, in order to determine the root length, volume and surface.

Data were subjected to analysis of variance and differences between the treatments were measured by the Tukey test at $5 \%$ of probability, based on the mean data of five replications. All analyses were carried out in the SAEG statistical software.

\section{RESULTS AND DISCUSSION}

The lowest values of plant height increase due to cultivation time (Figure 1) were recorded for the control treatment (without green manure and without biochar), as well as the highest values of it

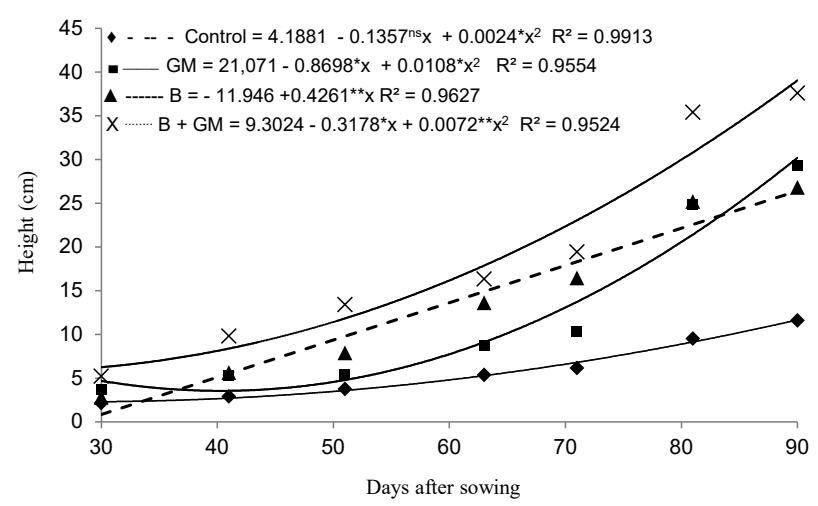

Figure 1. Shoot height in papaya plants subjected to treatments based on green manure (GM), biochar (B) and biochar + green manure $(B+G M)$ application, as well as in untreated plants (control), based on cultivation time. due to the application of biochar + green manure. The treatment with biochar and the one with green manure recorded a similar plant height at 90 days (Figure 1). The highest plant height was recorded for the treatment based on biochar + green manure application $(37.60 \mathrm{~cm})$. This rapid plant development, which reached $240 \%$ of difference between the control and biochar + green manure treatments in the current study, is fundamental at all papaya crop stages.

Plant height is an essential physiological feature, since it concerns, in a practical way, plant growth and differentiation. It is also a fundamental phytotechnical feature when it comes to maximum plant nutrition optimization (Vichiato 2005). Plant height defines the stage at which papaya seedlings must go to the field. According to Costa et al. (2003), the standard height of papaya seedlings produced in the Espírito Santo state ranges from $12 \mathrm{~cm}$ to $20 \mathrm{~cm}$ - plants at this stage present two to four pairs of leaves. Plants subjected to the biochar + mucuna application in the current study were $12 \mathrm{~cm}$ tall within approximately 52 days, whereas plants subjected to individual biochar and mucuna application reached this height at 56 days and 70 days, respectively, and the control plants did not reach the minimum height. Crop management techniques capable of improving seedling growth can decrease their time of permanence in the nursery. This feature is important in the field, because seedlings are more likely to win the natural competition with other species, such as spontaneous plants. The biochar + green manure application enabled a higher plant height than the other treatments in the first evaluation, which was performed at 30 days after planting, and this outcome remained unchanged until the last evaluation.

The biochar and green manure application did not seem to have a significant influence on plant growth (height, diameter at the stem base, shoot dry matter and root surface) (Table 1). The biochar application increased the shoot dry mass by $230 \%$, the diameter at the stem base by $48 \%$ and the plant height by $57 \%$, whereas the green manure application increased the plant dry mass by $18 \%$ and the plant height and diameter by $74 \%$.

The $224 \%, 184 \%$ and $317 \%$ increases recorded for height, diameter at stem base and shoot dry mass, respectively, in plants subjected to the biochar + green manure application, were not significant, in comparison to the control. Partey et al. 
Table 1. Shoot and root growth in papaya plants grown in pots $\left(4 \mathrm{dm}^{-3}\right)$, for 90 days, in the absence $(\mathrm{A})$ or presence $(\mathrm{P})$ of green manure (GM) biomass [Mucuna aterrina (Piper \& Tracy)], and in the absence or presence of biochar (B).

\begin{tabular}{|c|c|c|c|c|c|c|c|c|}
\hline $\mathrm{B} / \mathrm{GM}$ & $\mathrm{A} / \mathrm{GM}$ & $\mathrm{P} / \mathrm{GM}$ & Mean & $\mathrm{CV}(\%)$ & $\mathrm{A} / \mathrm{GM}$ & P/GM & Mean & $\mathrm{CV}(\%)$ \\
\hline & \multicolumn{4}{|c|}{ Height $(\mathrm{cm})$} & \multicolumn{4}{|c|}{ Diameter at the stem base $(\mathrm{mm})$} \\
\hline $\mathrm{A} / \mathrm{B}$ & 11.60 & 29.30 & $20.45 \mathrm{~B}$ & 21 & 5.54 & 12.28 & $8.90 \mathrm{~B}$ & 14 \\
\hline $\mathrm{P} / \mathrm{B}$ & 26.80 & 37.60 & $32.20 \mathrm{~A}$ & & 10.54 & 15.77 & $13.15 \mathrm{~A}$ & \\
\hline \multirow[t]{2}{*}{ Mean } & $19.20 \mathrm{~b}^{*}$ & $33.42 \mathrm{a}$ & & & $8.04 \mathrm{~b}$ & $14.02 \mathrm{a}$ & & \\
\hline & \multicolumn{4}{|c|}{ Shoot dry biomass (mg) } & \multicolumn{4}{|c|}{ Root length $(\mathrm{cm})$} \\
\hline $\mathrm{A} / \mathrm{B}$ & 0.38 & 0.37 & $0.38 \mathrm{~B}$ & 23 & $2,572 \mathrm{bB}$ & $43,544 \mathrm{aA}$ & $23,058 \mathrm{~A}$ & 7 \\
\hline $\mathrm{P} / \mathrm{B}$ & 0.99 & 1.25 & $1.12 \mathrm{~A}$ & & $31,156 \mathrm{aA}$ & $43,659 \mathrm{aA}$ & $37,408 \mathrm{~A}$ & \\
\hline \multirow[t]{2}{*}{ Mean } & $0.69 \mathrm{~b}$ & $0.81 \mathrm{a}$ & & & $16,864 \mathrm{~b}$ & $43,602 \mathrm{a}$ & & \\
\hline & \multicolumn{4}{|c|}{ Root surface $\left(\mathrm{cm}^{2}\right)$} & \multicolumn{4}{|c|}{ Root volume $\left(\mathrm{cm}^{3}\right)$} \\
\hline $\mathrm{A} / \mathrm{B}$ & 474 & 11,021 & 5,748 & 9 & $0.62 \mathrm{bB}$ & $22.25 \mathrm{aA}$ & $11.435 \mathrm{~B}$ & 35 \\
\hline $\mathrm{P} / \mathrm{B}$ & 14,386 & 14,262 & 14,324 & & $54.99 \mathrm{aA}$ & $37.23 \mathrm{aA}$ & $46.11 \mathrm{~A}$ & \\
\hline Mean & 7,430 & 12,642 & & & $27.81 \mathrm{a}$ & $29.74 \mathrm{a}$ & & \\
\hline
\end{tabular}

(2014) found a $35 \%$ increase in grain yield, in maize plants subjected to biochar + Tithonia diversifolia, as well as a $25 \%$ increase in plants subjected to biochar + Vicia faba, in comparison to the individual green manure application. This outcome was attributed to the increased $\mathrm{N}$ use efficiency in maize plants subjected to the joint biochar/green manure application or to the inorganic fertilizer application.

The biochar and green manure application presented a significant interaction for plant root length and volume (Table 1). The biochar, green manure and biochar + green manure applications increased the root length by $1,111 \%, 1,793 \%$ and $1,597 \%$, whereas the root volume increased by $8,770 \%, 3,490 \%$ and $5,870 \%$, respectively. The root surface did not present a significant increase. This finding indicates that, overall, the individual or joint application of green manure and biochar had positive effects on the development of the papaya root system, which plays a key role in the plant survival, mainly under stressful conditions such as water deficit or nutrient deficiency.

Based on nutritional evaluations (Table 2), only the $\mathrm{P}$ concentration in the shoot showed a significant interaction due to the biochar and green manure application, whereas the other nutritional evaluations (nutrient concentration, accumulation and use efficiency) did not show significant interactions between the aforementioned applications. The individual application of green manure or biochar reduced the $\mathrm{P}$ concentrations, whereas the joint application of these elements increased the $\mathrm{P}$ concentrations by $262 \%$, fact that indicates a synergistic effect. Overall, the $\mathrm{P}$ concentration increased by $8 \%$ after the biochar application, whereas the green manure application did not change such concentration.

The biochar application enabled a significantly higher nutrient accumulation and use efficiency values than the non-application of it, whereas the green manure application did not enable significant changes in all the evaluated elements (Table 2).

The biochar application increased the nutrient accumulation by $185 \%, 360 \%, 209 \%$ and $184 \%$, respectively for $\mathrm{N}, \mathrm{K}, \mathrm{Ca}$ and $\mathrm{Mg}$, in comparison to the non-application of it (Table 2). It also increased the nutrient use efficiency in the plant shoot by $283 \%$, $177 \%, 78 \%, 250 \%$ and $283 \%$, respectively for $\mathrm{N}$, $\mathrm{P}, \mathrm{K}, \mathrm{Ca}$ and $\mathrm{Mg}$ (Table 2). Nutrient use efficiency refers to the plant ability to convert absorbed nutrients into biomass.

Besides $\mathrm{P}, \mathrm{K}$ was the only nutrient presenting significantly different concentrations in the plant shoot between the herein applied treatments (Table 2). The green manure application increased this nutrient concentration by $33 \%$, whereas the biochar application increased it by $55 \%$. Sousa \& Figueiredo (2015) evaluated the incorporation of increasing sewage sludge-derived biochar doses into soil planted with radish and found increased $\mathrm{P}$ concentrations in the soil and plants, with biochar doses ranging from $10 \mathrm{~g} \mathrm{~kg}^{-1}$ to $30 \mathrm{~g} \mathrm{~kg}^{-1}$. The application of $2.76 \mathrm{~g} \mathrm{dm}^{-3}$ of biochar (approximately $30 \%$ of the lowest dose tested by the aforementioned authors) in the current study was enough to enable positive effects on the $\mathrm{P}$ and $\mathrm{K}$ accumulation, nutrient use efficiency and concentration in the shoot of papaya plants. However, plants subjected to the biochar + green manure and 
Table 2. Nutrient accumulation, use efficiency and concentration, and reading of SPAD values (green color intensity) in papaya leaves grown in pots $\left(4 \mathrm{dm}^{3}\right)$, for 90 days, in the absence $(\mathrm{A})$ or presence $(\mathrm{P})$ of green manure $(\mathrm{GM})$ biomass $[$ Mucuna aterrina (Piper \& Tracy)] and in the presence or absence of biochar (B).

\begin{tabular}{|c|c|c|c|c|c|c|c|c|}
\hline $\mathrm{B} / \mathrm{GM}$ & A/GM & $\mathrm{P} / \mathrm{GM}$ & Mean & $\mathrm{CV}(\%)$ & $\mathrm{A} / \mathrm{GM}$ & P/GM & Mean & $\mathrm{CV}(\%)$ \\
\hline & \multicolumn{4}{|c|}{$-\mathrm{N}$ accumulation $\left(\mathrm{mg}\right.$ plant $\left.^{-1}\right)$} & \multicolumn{4}{|c|}{ P accumulation (mg plant $\left.{ }^{-1}\right)$} \\
\hline $\mathrm{A} / \mathrm{B}$ & 6.21 & 11.77 & $8.96 \mathrm{~B}^{*}$ & \multirow[t]{3}{*}{40} & 0.29 & 0.29 & $0.29 \mathrm{~B}$ & \multirow[t]{2}{*}{33} \\
\hline $\mathrm{P} / \mathrm{B}$ & 25.31 & 33.38 & $29.35 \mathrm{~A}$ & & 0.85 & 1.25 & $1.05 \mathrm{~A}$ & \\
\hline \multirow[t]{2}{*}{ Mean } & 15.76 & 22.57 & & & 0.57 & 0.77 & & \\
\hline & \multicolumn{4}{|c|}{$\mathrm{K}$ accumulation $\left(\mathrm{mg} \mathrm{plant}^{-1}\right)$} & \multicolumn{4}{|c|}{ Ca accumulation $\left(\mathrm{mg} \mathrm{plant}^{-1}\right)$} \\
\hline $\mathrm{A} / \mathrm{B}$ & 3.08 & 5.56 & $4.32 \mathrm{~B}$ & 44 & 4.63 & 6.35 & $5.49 \mathrm{~B}$ & 32 \\
\hline $\mathrm{P} / \mathrm{B}$ & 16.61 & 23.16 & $19.89 \mathrm{~A}$ & & 15.23 & 18.75 & $16.99 \mathrm{~A}$ & \\
\hline \multirow[t]{2}{*}{ Mean } & 9.85 & 14.36 & & & 9.93 & 12.55 & & \\
\hline & \multicolumn{4}{|c|}{$\mathrm{Mg}$ accumulation $\left(\mathrm{mg}\right.$ plant $\left.^{-1}\right)$} & \multicolumn{4}{|c|}{$\mathrm{N}$ use efficiency $\left(\mathrm{g}^{2} \mathrm{~g}^{-1}\right)$} \\
\hline $\mathrm{A} / \mathrm{B}$ & 3.90 & 4.58 & $4.24 \mathrm{~B}$ & 30 & 10.98 & 11.94 & $11.46 \mathrm{~B}$ & 44 \\
\hline $\mathrm{P} / \mathrm{B}$ & 11.01 & 13.07 & $12.04 \mathrm{~A}$ & & 40.59 & 47.26 & $43.93 \mathrm{~A}$ & \\
\hline \multirow[t]{2}{*}{ Mean } & 7.46 & 8.83 & & & 25.79 & 29.60 & & \\
\hline & \multicolumn{4}{|c|}{ P use efficiency $\left(\mathrm{g}^{2} \mathrm{~g}^{-1}\right)$} & \multicolumn{4}{|c|}{ K use efficiency $\left(g^{2} g^{-1}\right)$} \\
\hline $\mathrm{A} / \mathrm{B}$ & 316.49 & 479.52 & $398.01 \mathrm{~B}$ & 40 & 46.26 & 25.29 & 35.78 & 42 \\
\hline $\mathrm{P} / \mathrm{B}$ & $1,153.58$ & $1,251.58$ & $1,202.58 \mathrm{~A}$ & & 59.99 & 67.43 & 63.71 & \\
\hline \multirow[t]{2}{*}{ Mean } & 734.54 & 865.55 & & & 53.13 & 46.36 & & \\
\hline & \multicolumn{4}{|c|}{$\longrightarrow$ Ca use efficiency $\left(\mathrm{g}^{2} \mathrm{~g}^{-1}\right)$} & \multicolumn{4}{|c|}{ Mg use efficiency $\left(g^{2} g^{-1}\right)$} \\
\hline $\mathrm{A} / \mathrm{B}$ & 20.63 & 22.28 & $21.46 \mathrm{~B}$ & 45 & 24.04 & 30.58 & $27.31 \mathrm{~B}$ & 44 \\
\hline $\mathrm{P} / \mathrm{B}$ & 64.63 & 85.63 & $75.13 \mathrm{~A}$ & & 88.92 & 120.63 & $104.78 \mathrm{~A}$ & \\
\hline \multirow[t]{2}{*}{ Mean } & 42.63 & 53.56 & & & 56.48 & 75.61 & & \\
\hline & \multicolumn{4}{|c|}{$\mathrm{N}$ concentration $\left(\mathrm{g} \mathrm{kg}^{-1}\right)$} & \multicolumn{4}{|c|}{$\mathrm{P}$ concentration $\left(\mathrm{g} \mathrm{kg}^{-1}\right)$} \\
\hline $\mathrm{A} / \mathrm{B}$ & 28.08 & 32.69 & 30.39 & 20 & $0.94 \mathrm{aA}$ & $0.80 \mathrm{bB}$ & $0.87 \mathrm{~B}$ & 6 \\
\hline $\mathrm{P} / \mathrm{B}$ & 26.40 & 26.81 & 26.61 & & $0.86 \mathrm{bB}$ & $1.01 \mathrm{aA}$ & $0.94 \mathrm{~A}$ & \\
\hline \multirow[t]{2}{*}{ Mean } & 27.24 & 29.75 & & & $0.90 \mathrm{a}$ & $0.91 \mathrm{a}$ & & \\
\hline & \multicolumn{4}{|c|}{$-\mathrm{K}$ concentration $\left(\mathrm{g} \mathrm{kg}^{-1}\right)$} & \multicolumn{4}{|c|}{ Ca concentration $\left(\mathrm{g} \mathrm{kg}^{-1}\right)$} \\
\hline $\mathrm{A} / \mathrm{B}$ & 8.21 & 14.31 & $11.26 \mathrm{~B}$ & 20 & 16.15 & 17.92 & 17.04 & 18 \\
\hline $\mathrm{P} / \mathrm{B}$ & 16.45 & 18.48 & $17.47 \mathrm{~A}$ & & 15.41 & 15.75 & 15.58 & \\
\hline \multirow[t]{2}{*}{ Mean } & $12.33 \mathrm{~b}$ & $16.40 \mathrm{a}$ & & & 15.78 & 16.84 & & \\
\hline & \multicolumn{4}{|c|}{$\mathrm{Mg}$ concentration $\left(\mathrm{g} \mathrm{kg}^{-1}\right)$} & & $\mathrm{SH}$ & 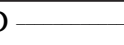 & \multirow{3}{*}{10} \\
\hline $\mathrm{A} / \mathrm{B}$ & 13.83 & 12.67 & 13.25 & & 43.56 & 47.76 & $45.66 \mathrm{~A}$ & \\
\hline $\mathrm{P} / \mathrm{B}$ & 11.23 & 10.73 & 10.98 & & 40.44 & 37.72 & $39.08 \mathrm{~B}$ & \\
\hline Mean & 12.53 & 11.70 & & & 42.00 & 42.74 & & \\
\hline
\end{tabular}

biochar (in a more discreet way) treatments started presenting nutritional deficiency symptoms at 80 days after sowing. Among these symptoms is a uniform chlorosis in basal leaves at first, and in younger leaves later on, similarly to the case characterized by Costa \& Costa (2003), who investigated the N deficiency in papaya plants.

The quantification of photosynthetic pigments (chlorophylls and carotenoids) was evaluated through a SPAD reading (Table 2 ) and, based on the results, the biochar application led to the lowest photosynthetic pigment values, which were confirmed through visual observations of increased leaf yellowing in the plants subjected to these treatments. This result corroborates the one observed by Matos et al. (2018), who also investigated papaya plants grown in soil treated with biochar. According to Torres Netto et al. (2002), SPAD reading values lower than 40 indicate a low $\mathrm{N}$ concentration in papaya plants. These values were associated with the $\mathrm{N}$ deficiency symptoms observed in plants subjected to biochar application. The highest SPAD reading value was recorded for the individual green manure application (47.76). This value also corresponded to the visual evaluation of increased green color intensity; however, the $\mathrm{N}$ content increase of $16 \%$ found in papaya leaves after the green manure application was not significant in the present experiment, when compared to the control.

Vichiato (2005) also found a high $\mathrm{N}$ accumulation associated with reduced concentrations 
of this nutrient in the shoot dry matter of papaya plants. According to the aforementioned author, the decreased $\mathrm{N}$ concentration resulted from the dilution effect caused by the increased shoot dry matter production. The same effect was observed in the present study, whose papaya plants grown in the presence of biochar and biochar + green manure presented a fast growth in height (figure 1) and a high biomass production (Table 1). However, they did not show any response to $\mathrm{N}, \mathrm{Ca}$ and $\mathrm{Mg}$ concentrations and recorded low SPAD values (Table 2).

The microbial analysis performed at 60 days after sowing recorded interactions between green manure and biochar for total fungi (Table 3). The highest total fungi values were recorded for the individual green manure application (394\% increase), whereas the biochar application recorded a total fungi decrease of $230 \%$ and the biochar + green manure application did not record any change in this parameter. The total number of bacterial colonies did not significantly change after the biochar, green manure or biochar + green manure application, despite differences of $368 \%, 187 \%$ and $133 \%$, respectively, in comparison to the control. Differences between the treatments were not significant, due to the large variability between replicates, as shown in the herein recorded high coefficient of variation $(50 \%)$.

The green manure decomposition may have led to these responses in the microbial analysis. On the other hand, the biochar application did not increase the fungal activity; instead, it decreased the fungal activity. According to Barcelos et al. (2017), biochar has a positive effect on the fungal population density at 20 days after its application. It was followed by soil incubation, what may have happened due to the entry of nutrients available in the soil. However, the

Table 3. Microbiological and chemical features of the soil after papaya plant cultivation in pots $\left(4 \mathrm{dm}^{-3}\right)$, for 90 days, in the absence (A) and presence (P) of green manure (GM) biomass [Mucuna aterrina (Piper \& Tracy)] and in the absence and presence of biochar (B).

\begin{tabular}{|c|c|c|c|c|c|c|c|c|}
\hline $\mathrm{B} / \mathrm{GM}$ & $\mathrm{A} / \mathrm{GM}$ & $\mathrm{P} / \mathrm{GM}$ & Mean & $\mathrm{CV}(\%)$ & $\mathrm{A} / \mathrm{GM}$ & $\mathrm{P} / \mathrm{GM}$ & Mean & $\mathrm{CV}(\%)$ \\
\hline & \multicolumn{4}{|c|}{ Total fungi $\left(10^{-4}\right)$} & \multicolumn{4}{|c|}{ Total bacteria $\left(10^{-3}\right)$} \\
\hline $\mathrm{A} / \mathrm{B}$ & $1.65 \mathrm{bB} *$ & $8.15 \mathrm{aA}$ & $4.90 \mathrm{~A}$ & 18 & 3.75 & 17.55 & $10.63 \mathrm{~A}$ & 50 \\
\hline $\mathrm{P} / \mathrm{B}$ & $0.50 \mathrm{aA}$ & $1.65 \mathrm{aB}$ & $1.07 \mathrm{~B}$ & & 10.75 & 8.75 & $9.75 \mathrm{~A}$ & \\
\hline \multirow[t]{2}{*}{ Mean } & $1.07 \mathrm{~b}$ & $4.90 \mathrm{a}$ & & & $7.25 \mathrm{a}$ & $13.13 \mathrm{a}$ & & \\
\hline & \multicolumn{4}{|c|}{$\longrightarrow \mathrm{pH}\left(\mathrm{H}_{2} \mathrm{O}\right)-$} & \multicolumn{4}{|c|}{$\mathrm{P}\left(\mathrm{mg} \mathrm{dm}^{-3}\right)^{* *}$} \\
\hline $\mathrm{A} / \mathrm{B}$ & 5.85 & 5.30 & 5.58 & 21 & 6.50 & 89.50 & $48.00 \mathrm{~B}$ & 10 \\
\hline $\mathrm{P} / \mathrm{B}$ & 4.50 & 6.25 & 5.38 & & 77.00 & 136.00 & $106.50 \mathrm{~A}$ & \\
\hline \multirow[t]{2}{*}{ Mean } & 5.18 & 5.78 & & & \multicolumn{4}{|c|}{$112.75 \mathrm{a}$} \\
\hline & \multicolumn{4}{|c|}{$\mathrm{K}\left(\mathrm{mg} \mathrm{dm}^{-3}\right)^{* *}$} & & $-\mathrm{Ca}(\mathrm{cmol}$ & $\left.\mathrm{m}^{-3}\right)^{* * *}$ & \\
\hline $\mathrm{A} / \mathrm{B}$ & $119.50 \mathrm{aB}$ & $176.00 \mathrm{aA}$ & $147.45 B$ & 14 & $1.70 \mathrm{bB}$ & $2.35 \mathrm{aA}$ & $2.03 \mathrm{~A}$ & 5 \\
\hline $\mathrm{P} / \mathrm{B}$ & $231.00 \mathrm{aA}$ & $175.50 \mathrm{aA}$ & $203.25 \mathrm{~A}$ & & $2.65 \mathrm{aA}$ & $2.25 \mathrm{bA}$ & $2.45 \mathrm{~A}$ & \\
\hline \multirow[t]{2}{*}{ Mean } & $175.25 \mathrm{a}$ & $175.75 \mathrm{a}$ & & & $2.18 \mathrm{a}$ & $2.30 \mathrm{a}$ & & \\
\hline & \multicolumn{4}{|c|}{$\mathrm{Mg}\left(\mathrm{cmol}_{\mathrm{c}} \mathrm{dm}^{-3}\right)^{* * *}$} & \multicolumn{4}{|c|}{$-\mathrm{H}+\mathrm{Al}\left(\mathrm{cmol}_{\mathrm{c}} \mathrm{dm}^{-3}\right)^{* / *}$} \\
\hline $\mathrm{A} / \mathrm{B}$ & $0.75 \mathrm{bB}$ & $1.05 \mathrm{aA}$ & $0.90 \mathrm{~A}$ & 6 & $1.35 \mathrm{bB}$ & $2.30 \mathrm{aA}$ & $1.83 \mathrm{~A}$ & 7 \\
\hline $\mathrm{P} / \mathrm{B}$ & $1.00 \mathrm{aA}$ & $1.00 \mathrm{aA}$ & $1.00 \mathrm{~A}$ & & $2.05 \mathrm{aA}$ & $1.30 \mathrm{bB}$ & $1.68 \mathrm{~A}$ & \\
\hline \multirow[t]{2}{*}{ Mean } & $0.88 \mathrm{~b}$ & $1.03 \mathrm{a}$ & & & \multicolumn{4}{|c|}{$1.80 \mathrm{a}$} \\
\hline & \multicolumn{4}{|c|}{$\mathrm{Na}\left(\mathrm{cmol}_{\mathrm{c}} \mathrm{dm}^{-3}\right)$} & & $\mathrm{C}(\%$ & $/ * /$ & \\
\hline $\mathrm{A} / \mathrm{B}$ & 0.13 & 0.08 & $0.10 \mathrm{~A}$ & 30 & $0.90 \mathrm{bA}$ & $1.47 \mathrm{aA}$ & $1.18 \mathrm{~A}$ & 6 \\
\hline $\mathrm{P} / \mathrm{B}$ & 0.25 & 0.10 & $0.17 \mathrm{~A}$ & & $1.16 \mathrm{aA}$ & $1.19 \mathrm{aA}$ & $1.17 \mathrm{~A}$ & \\
\hline \multirow[t]{2}{*}{ Mean } & $0.19 \mathrm{a}$ & $0.09 \mathrm{~b}$ & & & $1.03 \mathrm{~b}$ & $1.33 \mathrm{a}$ & & \\
\hline & \multicolumn{4}{|c|}{$\mathrm{SB}\left(\mathrm{cmol}_{\mathrm{c}} \mathrm{dm}^{-3}\right)$} & \multicolumn{4}{|c|}{$\mathrm{CEC}_{\text {total }}\left(\mathrm{cmol}_{\mathrm{c}} \mathrm{dm}^{-3}\right)$} \\
\hline $\mathrm{A} / \mathrm{B}$ & $2.88 \mathrm{bB}$ & $3.93 \mathrm{aA}$ & $3.40 \mathrm{~B}$ & 6 & $4.23 \mathrm{bB}$ & $6.23 \mathrm{aA}$ & $5.28 \mathrm{~B}$ & 3 \\
\hline $\mathrm{P} / \mathrm{B}$ & $4.49 \mathrm{aA}$ & $3.78 \mathrm{aA}$ & $4.13 \mathrm{~A}$ & & $6.54 \mathrm{aA}$ & $5.10 \mathrm{bB}$ & $5.88 \mathrm{~A}$ & \\
\hline \multirow[t]{2}{*}{ Mean } & $3.60 \mathrm{a}$ & $3.93 \mathrm{a}$ & & & $5.33 \mathrm{~b}$ & $5.83 \mathrm{a}$ & & \\
\hline & \multicolumn{4}{|c|}{$-\mathrm{CEC}_{\text {effective }}\left(\mathrm{cmol}_{\mathrm{c}} \mathrm{dm}^{-3}\right)$} & \multicolumn{4}{|c|}{$\mathrm{V}(\%)$} \\
\hline $\mathrm{A} / \mathrm{B}$ & $2.75 \mathrm{bB}$ & $4.05 \mathrm{aA}$ & $3.40 \mathrm{~B}$ & 5 & 68.04 & 63.06 & 64.20 & 5 \\
\hline $\mathrm{P} / \mathrm{B}$ & $4.40 \mathrm{aA}$ & $3.85 \mathrm{aA}$ & $4.13 \mathrm{~A}$ & & 68.61 & 74.74 & 70.33 & \\
\hline Mean & $3.58 \mathrm{a}$ & $3.95 \mathrm{a}$ & & & 67.75 & 67.78 & & \\
\hline
\end{tabular}


green manure (mucuna) did not have any effect on the total fungi, total bacteria and diazotrophic bacteria found in the soil, fact that indicates a stabilization in the population of these microorganisms.

Based on the chemical analysis of the soil (Table 3), there was no significant interaction between the treatments for $\mathrm{pH}$, as well as for the $\mathrm{P}$ and $\mathrm{Na}$ concentrations, after the papaya plant harvest. However, the biochar and green manure application increased the $\mathrm{P}$ concentration in the soil by $122 \%$ and $170 \%$, respectively. The $\mathrm{C}, \mathrm{Ca}, \mathrm{Mg}, \mathrm{H}+\mathrm{Al}$, sum of bases, total and effective cation exchange capacity showed interaction between the treatments and recorded significantly lower values in the control treatment, in comparison to the individual biochar or green manure application. This outcome indicates that biochar and green manure play a key role in maintaining the soil fertility.

$\mathrm{Mg}$ increased by $33 \%$ in all the treatments, in comparison to the control. This outcome indicates that, similarly to green manure, biochar can also maintain the nutrient level in the soil for longer. In the case of green manure, it is possible because of the already known cycling of biomass nutrients. On the other hand, much of the nutrients in the biochar mass is found in the labile form, maintaining large amounts of available forms in the soil. In addition, the increased soil carbon, total and effective cation exchange capacity (CEC) observed in the current study also indicate an increased soil fertility due to the biochar and green manure application, in comparison to pre-planting values $\left(\mathrm{CEC}_{\text {total }}=3.7 \mathrm{cmol}_{\mathrm{c}} \mathrm{dm}^{-3}\right.$; $\mathrm{CEC}_{\text {efetive }}=1.8 \mathrm{cmol}_{\mathrm{c}} \mathrm{dm}^{-3} ; \mathrm{C}=0.96 \%$ ) or to the control treatment (Table 3). On the other hand, the positive effects were not synergistic. Special attention should be paid to the sodium content, which increased by $92 \%$ after the biochar application.

Sousa \& Figueiredo (2015) observed a nutrient enrichment, mainly phosphorus, nitrogen and exchangeable cations, in the soil after the biochar application. Thus, such treatment was capable of providing nutrients to plants in the short term and led to an increased radish yield, which was attributed to the presence of nutrients available in the biochar. This response is similar to the one recorded for papaya plants in the present experiment, wherein the biochar application enabled a rapid initial plant growth (Figure 1), high nutrient accumulation in the shoot (Table 2) and increased soil fertility (Table 3 ).

\section{CONCLUSIONS}

1. The effect of the combined biochar/mucuna application is synergistic for the $\mathrm{P}$ content in the leaves and to the plant growth in height;

2. The individual or combined application of biochar and mucuna increases the papaya plant growth and nutrition, and maintains the soil fertility.

\section{ACKNOWLEDGMENTS}

The authors are grateful to the Fundação de Amparo à Pesquisa do Estado do Rio de Janeiro (FAPERJ), for supporting this study; and to Claudio Roberto Fonseca Souza (Universidade Federal de Santa Catarina), for providing the biochar.

\section{REFERENCES}

\section{ANUÁRIO BRASILEIRO DE FRUTICULTURA(ABF).} Santa Cruz do Sul: Gazeta, 2018.

BARCELOS, J. G. et al. Efeito do biocarvão associado ou não a composto orgânico ou ureia sobre a população microbiana em Espodossolo. In: VIEIRA, E. M. et al. (Eds.). Substâncias húmicas e matéria orgânica natural. São Carlos: Rima, 2017. p. 305-313.

BUNT, J. S.; ROVIRA, A. D. Microbiological studies of some subantartic soils. Journal of Soil Science, v. 6, n. 1, p. 119-128, 1955.

CLAESSEN, M. E. C. et al. Manual de métodos de análise de solo. Rio de Janeiro: Embrapa-CNPS, 1997.

COSTA, A. F. S. et al. Plantio, formação e manejo da cultura. In: MARTINS, D. S.; COSTA, A. F. S. (Eds.). $A$ cultura do mamoeiro: tecnologia de produção. Vitória: Incaper, 2003. p. 127-160.

COSTA, A. N.; COSTA, A. F. S. Nutrição e adubação. In: MARTINS, D. S.; COSTA, A. F. S. (Eds.). A cultura do mamoeiro: tecnologia de produção. Vitória: Incaper, 2003. p. 199-227.

KÖPPEN, W. Climatologia: con un estudio de los climas de la tierra. Ciudad de México: FCE, 1948.

KRATZ, D. et al. Propriedades físicas e químicas de substratos renováveis. Revista Árvore, v. 37, n. 6, p. 1103 1113, 2013.

MALAVOLTA, E. Manual de nutrição mineral de plantas. São Paulo: Agronômica Ceres, 2006.

MANGRICH, A. S.; MAIA, C. M. B. F.; NOVOTNY, E. H. Biocarvão: as terras pretas de índios e o sequestro de carbono. Ciência Hoje, v. 47, n. 281, p. 48-52, 2011. 
MARTIN, J. P. Use of acid, rose bengal, and streptomycin in the plate method for estimating soil fungi. Soil Science, v. 69, n. 3, p. 215-232, 1950.

MARTINS, C. C. Biochar: composto orgânico e potássio nas características químicas e lixiviação de nutrientes em Espodossolo e no cultivo de mucuna preta e moringa. 2018. 113 f. Tese (Doutorado em Produção Vegetal) - Universidade Estadual do Norte Fluminense Darcy Ribeiro, Campos dos Goytacazes, 2018.

MATOS, E. C. T. et al. Espectroscopia fotoacústica para analisar a fertilidade de solos tratados com biochar e micorriza. Química Nova, v. 41, n. 9, p. 989-998, 2018.

MINOLTA CAMERA CO. LTD. (MCCL). Manual for chlorophyll meter SPAD-502. Osaka: Minolta Radiometric Instruments, 1989.

MUKHERJEE, A.; ZIMMERMAN, A. R. Organic carbon and nutrient release from a range of laboratory-produced biochars and biochar-soil mixtures. Geoderma, v. 193-194, n. 1, p. 122-130, 2013.

NOVOTNY, E. H. et al. Pyrogenic carbon for agricultural use: a critical review. Revista Brasileira de Ciência do Solo, v. 39, n. 2, p. 321-344, 2015.

PARTEY, S. T.; PREZIOSI, R. F.; ROBSON, G. D. Short-term interactive effects of biochar, green manure, and inorganic fertilizer on soil properties and agronomic characteristics of maize. Agricultural Research, v. 3, n. 2, p. 128-136, 2014.
SIDDIQI, M. Y.; GLASS, A. D. M. Utilization index: a modified approach to the estimation and comparation of nutrient utilization efficiency in plants. Jounal of Plant Nutrition, v 4, n. 2, p. 289-302, 1981.

SOUSA, A. A. T. C.; FIGUEIREDO, C. C. Sewage sludge biochar: effects on soil fertility and growth of radish. Biological Agriculture \& Horticulture, v. 32, n. 2, p. $127-$ 138, 2015.

SUN, D. et al. Effect of volatile organic compounds absorbed to fresh biochar on survival of Bacillus mucilaginosus and structure of soil microbial communities. Journal of Soils and Sediments, v. 15, n. 2, p. 271-81, 2015.

SUZUKI, L. E. A. S.; ALVES, M. C. Fitomassa de plantas de cobertura em diferentes sucessões de culturas e sistemas de cultivo. Bragantia, v. 65, n. 1, p. 121-127, 2006.

TORRES NETTO, A. et al. Portable chlorophyll meter for the quantification of photosynthetic pigments, nitrogen and the possible use for assessment of the photochemical process in Carica papaya L. Brazilian Journal of Plant Physiology, v. 14, n. 3, p. 203-210, 2002.

VICHIATO, M. Nutrição mineral e crescimento de mudas de mamoeiro em função de fósforo e magnésio. 2005. 90 f. Tese (Doutorado em Fitotecnia) - Universidade Federal de Lavras, Lavras, 2005.

WOLLUM, A. G. Cultural methods for soil microorganisms. In: PAGE, A. L.; MILLER, R. H.; KEENEY, D. R. (Eds.). Methods of soil analysis. Madison: SSSA, 1982. p. 781-802. 